\title{
Integrated Management of Cheatgrass (Bromus tectorum) with Sheep Grazing and Herbicide
}

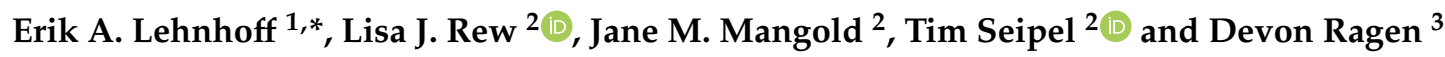 \\ 1 Department of Entomology, Plant Pathology and Weed Science, New Mexico State University, \\ Las Cruces, NM 88003, USA \\ 2 Department of Land Resources and Environmental Sciences, Montana State University, \\ Bozeman, MT 59717, USA; lrew@montana.edu (L.J.R.); jane.mangold@montana.edu (J.M.M.); \\ timothy.seipel@montana.edu (T.S.) \\ 3 Department of Animal and Range Sciences, Montana State University, Bozeman, MT 59717, USA; \\ devon.ragen@montana.edu \\ * Correspondence: lehnhoff@nmsu.edu; Tel.: +1-(575)-646-2328
}

Received: 22 May 2019; Accepted: 11 June 2019; Published: 14 June 2019

\begin{abstract}
Cheatgrass (Bromus tectorum L.) is one of the most problematic weeds in western United States rangelands and sagebrush steppe. It responds positively to different forms of disturbance, and its management has proven difficult. Herbicide or targeted grazing alone often fail to provide adequate long-term control. Integrating both may afford better control by providing multiple stressors to the weed. We assessed herbicide application, targeted sheep grazing and integrated herbicide and grazing on B. tectorum and the plant community in rangeland in southwestern Montana from 2015 until 2017. Herbicide treatments included spring-applied (May 2015 and 2016) glyphosate, fall-applied (October 2015) glyphosate, imazapic and rimsulfuron, and spring-applied glyphosate plus fall-applied imazapic. Targeted grazing, consisting of four sheep/0.01 ha for a day in $5 \mathrm{~m} \times 20 \mathrm{~m}$ plots (all vegetation removed to the ground surface), occurred twice (May 2015 and 2016). While no treatments reduced B. tectorum biomass or seed production, grazing integrated with fall-applied imazapic or rimsulfuron reduced B. tectorum cover from approximately $26 \%$ to $14 \%$ in 2016 and from $33 \%$ to $16 \%$ in 2017 , compared to ungrazed control plots, and by an even greater amount compared to these herbicides applied without grazing. By 2017, all treatments except spring-applied glyphosate increased total plant cover (excluding B. tectorum) by $8 \%-12 \%$ compared to the control plots, and forbs were generally responsible for this increase. Bromus tectorum management is difficult and our results point to a potential management paradox: Integrating grazing and fall-applied herbicide decreased $B$. tectorum cover but did not increase native grass cover, while some herbicides without grazing increased native grass cover, but failed to control B. tectorum. Additional research is necessary to determine grazing strategies that will complement herbicide control of $B$. tectorum while also stimulating native grass recovery, but this initial study demonstrates the potential of integrated management of B. tectorum compared to grazing or herbicide alone.
\end{abstract}

Keywords: downy brome; integrated weed management; novel ecosystem; restoration; soil disturbance

\section{Introduction}

Disturbance alters plant communities by removing existing vegetation or changing abiotic conditions, facilitating plant invasions [1,2]. After disturbance, some communities require intervention to alter the trajectory toward a desired state, although returning to the original plant community may not be possible $[3,4]$. The most common method to alter the trajectory of plant communities and remove undesired weeds is via herbicide application [5-7]. However, mortality of targeted weeds can vary 
based on abiotic conditions, growth rate, or life stage. Herbicides can also harm desired plants growing in the same community, especially closely related plants with the same life form as the weeds, such as rangeland grasses [8]. One approach to reduce undesired consequences of herbicide applications is to use herbicides that are selective. For example, the herbicide imazapic can control some weedy annual grass species with minimal impact to desired grass species $[9,10]$. Another approach is timing herbicide application to take advantage of different phenological stages of the weedy and desired species; ideally herbicides are applied when the desired species are dormant reducing off-target damage. For example, Morris et al. [11] determined that a spring application of glyphosate reduced the cover of cheatgrass (Bromus tectorum L., also known as downy brome) and had no effect on native grasses because of differences in growth stages or dormancy. Typically, managing weed populations to restore desired species is extremely difficult, and many populations persist despite repeated control efforts [12].

Another approach to alter the trajectory of a community and manage undesired species is targeted grazing with livestock. Kleppel and LaBarge [13] demonstrated that sheep grazing reduced purple loosestrife (Lythrum salicaria L.) cover by 41 percent and prevented it from flowering. Goats reduced yellow starthistle (Centaurea solstitialis L.) cover by $75 \%$ and seedheads by $94 \%$ with three years of grazing [14]. The efficacy and conservation benefits of targeted grazing can vary based on timing, duration, and intensity of grazing as well as the grazing species. High intensity spring grazing for short durations was most effective at reducing the abundance of the non-native annual grass medusahead (Taeniatherum caput-medusae L.), while native plant abundance increased for both sheep and cow grazing [15]. In a study on leafy spurge (Euphorbia esula L.), Rinella and Hileman [16] demonstrated that the overall effect of grazing on E. esula and native plants varied greatly depending on the timing, intensity, and frequency. Results suggested that removing small quantities of both native and invader biomass at early growth stages reduced the invader while increasing the resident species over time. These studies demonstrate the value of targeted grazing but also highlight that grazing timing, intensity, and frequency need to be defined for specific species and habitats.

Integrated weed management, designed to stress target plants at multiple life stages, is another approach to manage weeds [17] and achieve desired communities. Livestock grazing and herbicide can potentially be combined to provide multiple stressors and consequently improve weed management. Livestock can graze weeds in the spring, and then herbicide can be used to manage weeds that regrow later in the summer or fall when desired species are dormant. Alternatively, herbicide can be used to control early spring growth, and after an appropriate exclusion time (herbicide specific), livestock can graze the regrowth. Spring grazing combined with a fall application of 2,4-D reduced leafy spurge density more than either grazing or herbicide alone [18]. Similarly, spotted knapweed (Centaurea stoebe L.) rosette density was greatly reduced in plots with sheep grazing plus 2,4-D compared to individual treatments [19], and sheep grazing followed with fall imazapic application to leafy spurge sustained the productivity of desired plant biomass and prevented an increase of the leafy spurge seedbank [20].

Adopting an integrated weed management approach that uses grazing and herbicide application could improve the management of B. tectorum, one of the most problematic weeds in western North America. Bromus tectorum has a positive feedback with fire leading to its dominance in some areas [21-23], and the result is invasions covering millions of hectares of rangeland in the western USA [24]. Furthermore, B. tectorum is one of a few winter annual grasses in the western USA, a region that is dominated by shrubs and perennial grasses. The annual life history of $B$. tectorum allows it to utilize soil water early in the season, grow rapidly as temperatures warm, and complete its lifecycle while other species are still growing [25].

The dominance of B. tectorum across large areas of western USA has led to a plethora of research on B. tectorum management, yet this research has yielded little success in terms of controlling and reducing the extent and abundance of the species. A recent review of 119 journal articles by Monaco et al. [7] showed that while numerous control methods reduced B. tectorum biomass and cover in the short term (one year after treatment), only herbicide and revegetation were successful two years after 
treatment. Further, some methods such as burning increased B. tectorum cover long-term. Thus, despite considerable research throughout the western USA, reliable and affordable long-term control measures have not been developed.

Glyphosate, imazapic, and rimsulfuron are commonly used herbicides for managing B. tectorum [26], and while these herbicides have varying levels of selectivity, applying them when native plants are dormant minimizes their impact on desired vegetation [11]. Espeland et al. [27] determined that a low dose of glyphosate applied in spring and fall did not harm native grasses and reduced $B$. tectorum cover in the first year after spraying, but a second fall glyphosate application failed to reduce $B$. tectorum cover or seed bank. Morris et al. [11], however, determined that spring-applied glyphosate alone reduced $B$. tectorum cover for two years, and combining with imazapic provided even greater control. Imazapic has been widely used [28-31] because it provides residual soil activity, which is important for controlling annual plants such as B. tectorum, with early post-emergent fall application recommended [29].

Similar to applying herbicide at optimum times to limit off-target impacts, targeted grazing of B. tectorum infestations is best performed in the spring when native plants are still dormant, though research is scant. For example, cattle grazing for two consecutive years greatly reduced B. tectorum biomass and its presence in the seedbank, however, this approach had spatial and temporal limits because of the logistical issues with managing the cattle ( 83 cow-calf pairs ha $\left.{ }^{-1}\right)$ [32]. These results highlight the need for research on integrated management techniques for $B$. tectorum.

The lack of consistent success with $B$. tectorum management, especially where it has become dominant after a disturbance, indicates additional research on integrated management of $B$. tectorum with a longer period of monitoring is warranted. Our research took advantage of a site where B. tectorum had recently become the dominant species as the result of a mechanical soil disturbance in sagebrush steppe rangeland in southwestern Montana, USA. We used targeted sheep grazing, with or without herbicide, to assess the impacts of these management practices on B. tectorum abundance and seed production, native species abundance, and changes to plant community structure. Specifically, we expected that integrated management with sheep grazing and herbicide would (1) suppress B. tectorum cover, biomass, and seed production more than grazing or herbicide applications alone, and (2) facilitate an increase in forbs and native grasses. We also expected that (3) grazing and herbicide treatments would begin to shift plant communities dependent upon grazing, herbicide mode of action, and timing of application.

\section{Materials and Methods}

\subsection{Study Site}

Research was conducted at the Montana State University Red Bluff Research Ranch $\left(45.593^{\circ} \mathrm{N}\right.$, 111.628 W; hereafter Red Bluff), from 2015 to 2017. The soil was of the Nuley Rock outcrop complex, with a typical profile of sandy loam $(0-10 \mathrm{~cm})$, sandy clay loam $(10-28 \mathrm{~cm})$, gravelly sandy loam $(28-61 \mathrm{~cm})$, and gravelly coarse sand $(61-107 \mathrm{~cm})$ over unweathered bedrock [33]. Vegetation at the site was historically classified as Festuca idahoensis Elmer-Agropyron spicatum (i.e., Pseudoroegneria spicata (Pursh) Á. Löve) [34]. A moderate severity wildfire burned a portion of Red Bluff on 7 July 2012, and a bulldozer was used to create a fire-break to prevent the fire from spreading uphill. Bromus tectorum did not increase in canopy cover in the burned area compared to the unburned areas uphill; however, on the fire-break B. tectorum cover increased to approximately $18 \%, 33 \%$, and $38 \%$ in 2013 , 2014, and 2015, respectively, more than double the amount in the burned or unburned plots [35]. During the same time, native grasses in the burned and unburned plots averaged $\sim 27 \%$ cover while on the fire break native grass cover was approximately one third of this [35]. Thus, at the beginning or our study in 2015, the fire-break was dominated by B. tectorum, but native grasses including Hesperostipa comata (Trin. and Rupr.) Barkworth, Pascopyrum smithii (Rydb.) Á. Löve and P. spicata were also present in small amounts [35]. 


\subsection{Experimental Design}

A nested design (herbicide nested within grazing) was used to assess effects of grazing, herbicide application and the combination of herbicide and grazing (Table 1 ). Sixteen plots ( $4 \mathrm{~m}$ wide by $20 \mathrm{~m}$ long) were established along a $500 \mathrm{~m}$ portion of the fire-break. Plots were randomly assigned to be either grazed by sheep or ungrazed.

Table 1. List of treatments applied to manage cheatgrass at Red Bluff, Montana.

\begin{tabular}{lcccc}
\hline $\begin{array}{l}\text { Main Plot } \\
\text { Treatment }\end{array}$ & Subplot Treatment & Treatment Code ${ }^{\text {a }}$ & Date Applied & $\begin{array}{c}\text { Number of } \\
\text { Replicates }\end{array}$ \\
\hline Ungrazed & None & U_C & NA & 8 \\
Ungrazed & Spring glyphosate & U_Sg & $5 / 1 / 15 ; 5 / 3 / 16$ & 4 \\
Ungrazed & Spring glyphosate + fall imazapic & U_Sg_Fi & $5 / 1 / 15 ; 10 / 15 / 15 ; 5 / 3 / 16$ & 4 \\
Ungrazed & Fall glyphosate & U_Fg & $10 / 15 / 15$ & 4 \\
Ungrazed & Fall imazapic & U_Fi & $10 / 15 / 15$ & 8 \\
Ungrazed & Fall rimsulfuron & U_Fr & $10 / 15 / 15$ & 4 \\
Grazed & None & G_C & $5 / 4 / 15 ; 5 / 19 / 16$ & 8 \\
Grazed & Fall glyphosate & G_Fg & $10 / 15 / 15$ & 8 \\
Grazed & Fall imazapic & G_Fi & $10 / 15 / 15$ & 8 \\
Grazed & Fall rimsulfuron & G_Fr & $10 / 15 / 15$ & 8 \\
\hline
\end{tabular}

${ }^{\mathrm{a}} \mathrm{C}=$ control; $\mathrm{U}=$ ungrazed $\mathrm{S}$ = spring; $\mathrm{g}=$ glyphosate; $\mathrm{F}$ = fall; $\mathrm{i}=$ imazapic $; \mathrm{r}=$ rimsulfuron; $\mathrm{G}=$ grazed.

\subsection{Sheep Grazing}

Targeted, high intensity grazing occurred twice for 24 hours, first on 4-5 May 2015 and secondly on 19-20 May 2016, with four western whiteface sheep per plot (0.01 ha) until all forage was consumed (all vegetation removed to the ground surface). In 2015 sheep were non-pregnant, non-lactating mature ewes, approximately $62 \mathrm{~kg}$, and in 2016 they were non-pregnant, non-lactating 12 month yearlings, weighing approximately $43 \mathrm{~kg}$. Prior to being used in the experiment, sheep had been fed approximately $2.3 \mathrm{~kg}$ and $1.8 \mathrm{~kg}$ of second cutting grass/alfalfa hay per day, in 2015 and 2016, respectively. Portable electric fencing operated by a battery with a solar charger was installed around each grazed plot, with a $0.5 \mathrm{~m}$ buffer on all sides. After grazing in 2015, plots were divided into four subplots ( $4 \mathrm{~m}$ wide by $5 \mathrm{~m}$ long): Three subplots received one of three herbicide treatments and one subplot was not treated with herbicide.

\subsection{Herbicide Application}

Herbicide treatments included spring-applied glyphosate (Glyphomate ${ }^{\circledR}, 199.4 \mathrm{~g}_{\text {ai ha }}{ }^{-1}$, PBI/Gordon Corporation, 1217 West 12th St., Kansas City, MO, USA), fall-applied glyphosate (same rate as spring), fall-applied imazapic (Panoramic 2SL, $104.9 \mathrm{~g} \mathrm{ai} \mathrm{ha}^{-1}$, Alligare, LLC, $13 \mathrm{~N}$. 8th St., Opelika, $\mathrm{AL}$ ), fall-applied rimsulfuron (Matrix $\mathrm{SG}^{\circledR}, 48.3 \mathrm{~g}^{\circledR}$ ai ha ${ }^{-1}$, du Pont de Nemours and Company, 1007 Market Street, Wilmington, DE, USA), and spring-applied glyphosate + fall-applied imazapic (same rates as above; Table 1). Herbicide was applied at a total volume of 178 liters ha ${ }^{-1}$ with a $\mathrm{CO}_{2}$ powered backpack sprayer at $45 \mathrm{psi}$, using TeeJet nozzles. A non-ionic surfactant was added to the tank at $0.01 \%$ volume/volume. Relative humidity and temperature at the time of spraying were $43 \%$ and $13.3{ }^{\circ} \mathrm{C}$ in the spring and $40 \%$ and $13.9^{\circ} \mathrm{C}$ in the fall. Wind speeds averaged less than $5 \mathrm{~km} \mathrm{hr}^{-1}$ each year. Our original design was modified after high fall emergence of B. tectorum in 2015; in the ungrazed treatments we added a fall imazapic application to one half of the spring glyphosate subplots, and a fall-applied rimsulfuron treatment to one half of the subplots slated to receive glyphosate in the fall. This resulted in four replications for each of these treatments and fall glyphosate, while all other treatments had eight replications (Table 1). Herbicide application dates were 1 May 2015 (4-5 leaf stage) and 3 May 2016 (4-5 leaf stage) for the spring-applied glyphosate, and 16 October 2015 (2-4 leaf stage) for the fall-applied glyphosate, imazapic, and rimsulfuron. The sparse vegetation in fall 2016 did not warrant a second application of the fall herbicide treatments. 


\subsection{Data Collection}

Within each subplot, four $1 \mathrm{~m}^{2}$ frames were established for data collection. The four frames were situated such that there were $1 \mathrm{~m}$ and $0.5 \mathrm{~m}$ buffers from the short and long edges of the subplots, respectively. Canopy cover (\%) of each individual grass species was estimated ocularly on 1 May 2015 (1st year pre-treatment), 24 June 2015 (1st year post-treatment), 18 May 2016 (2nd year pre-treatment), and 14 June 2016 and 15 June 2017 (2nd and 3rd years post-treatment). Additionally, after senescence each year, B. tectorum was harvested from two $1 \mathrm{~m}^{2}$ areas within the subplots, with different areas being harvested each year to avoid sampling previously harvested areas. Biomass was dried at $40{ }^{\circ} \mathrm{C}$ for one week, weighed, and seeds were then separated from other plant material, weighed, and counted.

\subsection{Statistical Analysis}

Biomass, plant canopy cover (\%) and seed weight were analyzed using linear mixed effects models using the package "lme4" [36] in the R statistical environment [37]. Residual versus fitted value plots from an analysis of non-transformed data revealed heteroscedasticity, and data were corrected/improved with a log transformation. The models included treatment (see Table 1, column 3) as the fixed effect, and the random effect terms were frame, nested within replicate, and location of the plot across the site. This latter term was included to account for heterogeneity of the slope and aspect across the site. For analysis of June 2015 and 2016 B. tectorum biomass, cover, and seed production, the cover of B. tectorum recorded during the preceding May sampling was included as a random effect in the model. Means separation was via the package "lmerTest" and function "difflsmeans", which uses the Satterthwaite's approximation for degrees of freedom and calculates the differences of the least squares means. Non-transformed means are presented in figures for ease of interpretation.

Differences in plant communities among the treatments were assessed by non-metric multidimensional scaling (NMDS) with the package "vegan" [38]. The function "adonis" was used for permutational multivariate analysis of variance of the distance matrices for the different treatments, using 1000 permutations. Species rank-abundance (based on cover) was calculated with the package BiodiversityR [39].

\section{Results}

\subsection{Grazing}

Grazing alone did not reduce B. tectorum biomass, cover, or seed production in 2015, 2016, or 2017 compared to the ungrazed controls (Tables 2-4, Figures 1-3). The only exception to this was during the initial year of the study when grazed plots averaged $34 \%$ cover compared to $49 \%$ cover in ungrazed plots (Figure 2). The overall effects of grazing are similar to the results from Bates and Davies [40] who determined that even long-term grazing did not alter cover and production of $B$. tectorum compared to ungrazed plots following wildfire. Our results differ, however, from those of Diamond et al. [32] who determined that $B$. tectorum seed production was decreased in grazed compared to ungrazed plots: We determined no differences, but grazing occurred twice within a season in their study and only once in ours. A second grazing of our plots, or grazing later in the season, could potentially have reduced $B$. tectorum seed production, but this could have been at the expense of native plant growth [16]. The window of opportunity at our site for grazing $B$. tectorum while desired species are dormant is minimal, emphasizing the difficulty in implementing prescribed grazing in this northern sagebrush steppe system. 
Table 2. The response of Bromus tectorum biomass to grazing and/or herbicide treatments, analyzed using a linear mixed effects model. All treatments (parameters) are with respect to the ungrazed control treatment (U_C), which is the intercept in the model. In 2015 only the grazed (G) and ungrazed control, and the spring applied herbicide treatment results are shown, because fall herbicide application had not yet occurred. Results are based on log transformed B. tectorum biomass.

\begin{tabular}{|c|c|c|c|c|c|c|c|}
\hline \multicolumn{2}{|c|}{ Fixed Effects } & \multirow[b]{2}{*}{ Estimate } & \multirow[b]{2}{*}{ SE } & \multirow[b]{2}{*}{$t$ Value } & \multirow[b]{2}{*}{$\operatorname{Pr}(>|t|)^{b}$} & \multicolumn{2}{|c|}{ Random Effects } \\
\hline Year & Parameter $^{a}$ & & & & & Group & Variance \\
\hline \multirow[t]{5}{*}{2015} & Intercept & 2.27 & 0.18 & 12.3 & $<0.001$ & pBROTE $^{c}$ & 0.82 \\
\hline & G_C & -0.15 & 0.11 & -1.35 & 0.181 & Frame/Rep & 0.07 \\
\hline & U_Sg & -0.76 & 0.18 & -4.27 & $<0.001$ & Rep & 0.00 \\
\hline & & & & & & Location & 0.01 \\
\hline & & & & & & Residual & 0.53 \\
\hline \multirow[t]{10}{*}{2016} & Intercept & 2.42 & 0.38 & 6.43 & $<0.001$ & pBROTE & 0.88 \\
\hline & G_C & 0.27 & 0.38 & 0.71 & 0.481 & Frame/Rep & 0.00 \\
\hline & G_Fg & 0.20 & 0.34 & 0.58 & 0.564 & Rep & 0.11 \\
\hline & G_Fi & 0.04 & 0.35 & 0.11 & 0.911 & Location & 0.49 \\
\hline & G_Fr & 0.19 & 0.36 & 0.54 & 0.592 & Residual & 0.86 \\
\hline & U_Fg & -0.02 & 0.41 & -0.05 & 0.962 & & \\
\hline & U_Fi & 0.33 & 0.35 & 0.95 & 0.345 & & \\
\hline & U_Fr & 0.91 & 0.44 & 2.06 & 0.042 & & \\
\hline & U_Sg & 0.11 & 0.44 & 0.25 & 0.800 & & \\
\hline & U_Sg_Fi & 0.41 & 0.43 & 0.96 & 0.341 & & \\
\hline \multirow[t]{10}{*}{2017} & Intercept & 3.04 & 0.39 & 7.34 & $<0.001$ & Frame/Rep & 0.00 \\
\hline & G_C & -0.36 & 0.32 & -1.13 & 0.260 & Rep & 0.18 \\
\hline & G_Fg & -0.33 & 0.32 & -1.03 & 0.305 & Location & 0.64 \\
\hline & G_Fi & -0.59 & 0.32 & -1.88 & $0.063 *$ & Residual & 0.89 \\
\hline & G_Fr & -0.14 & 0.32 & -0.45 & 0.657 & & \\
\hline & U_Fg & -0.67 & 0.39 & -1.71 & 0.091 * & & \\
\hline & U_Fi & 0.36 & 0.31 & 1.16 & 0.250 & & \\
\hline & U_Fr & 0.66 & 0.39 & 1.70 & $0.092 *$ & & \\
\hline & U_Sg & -0.11 & 0.39 & -0.28 & 0.780 & & \\
\hline & U_Sg_Fi & -0.09 & 0.39 & -0.24 & 0.811 & & \\
\hline
\end{tabular}

a ${ }^{\text {G_C }}$ = grazed control, G_Fg = grazed + fall glyphosate, G_Fi = grazed + fall imazapic, U_Fg = ungrazed + fall glyphosate, U_Fi = ungrazed + fall imazapic, U_Fr = ungrazed + fall rimsulfuron, U_Sg = ungrazed + spring glyphosate, $\mathrm{U}_{-} \mathrm{Sg}$-Fi $=$ ungrazed + spring glyphosate + fall imazapic. ${ }^{\mathrm{b}}$ Bold values indicate significance at a $p$ value of $<0.05 .{ }^{*}=$ significance at $p$ value of $<0.10 .{ }^{c}$ Pre-treatment amount of Bromus tectorum from May sampling in the respective year.

Table 3. The response of Bromus tectorum cover to grazing and/or herbicide treatments, analyzed using a linear mixed effects model. All treatments (parameters) are with respect to the ungrazed control treatment (U_C), which is the intercept in the model. In 2015 only the grazed (G) and ungrazed control, and the spring applied herbicide treatment results are shown, because fall herbicide application had not yet occurred. Results are based on log transformed B. tectorum cover.

\begin{tabular}{cccccccc}
\hline \multicolumn{2}{c}{ Fixed Effects } & & & & & \multicolumn{2}{c}{ Random Effects } \\
\hline Year & Parameter $^{\text {a }}$ & Estimate & SE & $\boldsymbol{t}$ Value & Pr $(>|\mathbf{t}| \mathbf{b}$ & Group & Variance \\
\hline 2015 & Intercept & 3.67 & 0.14 & 25.4 & $<\mathbf{0 . 0 0 1}$ & pBROTE c & 0.65 \\
& G_C & -0.32 & 0.04 & -4.42 & $<\mathbf{0 0 1}$ & Frame/Rep & 0.22 \\
& U_Sg & -0.25 & 0.11 & -2.20 & $\mathbf{0 . 0 2 9}$ & Rep & 0.09 \\
& & & & & Location & 0.00 \\
& & & & & Residual & 0.50 \\
\hline 2016 & Intercept & 2.97 & 0.17 & 17.5 & $<\mathbf{0 . 0 0 1}$ & pBROTE & 0.82 \\
& G_C & -0.00 & 0.16 & -0.02 & 0.987 & Frame/Rep & 0.00 \\
& G_Fg & 0.05 & 0.14 & 0.35 & 0.728 & Rep & 0.19 \\
& G_Fi & -0.26 & 0.15 & -1.70 & $0.090 *$ & Location & 0.03 \\
\hline
\end{tabular}


Table 3. Cont.

\begin{tabular}{|c|c|c|c|c|c|c|c|}
\hline \multicolumn{2}{|c|}{ Fixed Effects } & \multirow[b]{2}{*}{ Estimate } & \multirow[b]{2}{*}{ SE } & \multirow[b]{2}{*}{$t$ Value } & \multirow[b]{2}{*}{$\operatorname{Pr}(>|t|)^{b}$} & \multicolumn{2}{|c|}{ Random Effects } \\
\hline Year & Parameter $^{a}$ & & & & & Group & Variance \\
\hline \multirow[t]{6}{*}{2016} & G_Fr & -0.21 & 0.15 & -1.35 & 0.179 & Residual & 0.54 \\
\hline & U_Fg & 0.03 & 0.18 & 0.16 & 0.875 & & \\
\hline & U_Fi & 0.10 & 0.15 & 0.60 & 0.551 & & \\
\hline & U_Fr & 0.35 & 0.19 & 1.87 & $0.063 *$ & & \\
\hline & U_Sg & -0.04 & 0.19 & -0.19 & 0.848 & & \\
\hline & U_Sg_Fi & -0.29 & 0.19 & -1.55 & 0.123 & & \\
\hline \multirow[t]{10}{*}{2017} & Intercept & 2.84 & 0.35 & 8.13 & $<0.001$ & Frame/Rep & 0.00 \\
\hline & G_C & -0.34 & 0.21 & -1.59 & 0.11 & Rep & 0.37 \\
\hline & G_Fg & -0.39 & 0.21 & -1.84 & $0.07 *$ & Location & 0.58 \\
\hline & G_Fi & -0.61 & 0.21 & -2.91 & 0.004 & Residual & 0.854 \\
\hline & G_Fr & -0.47 & 0.21 & -2.21 & 0.028 & & \\
\hline & U_Fg & -0.32 & 0.27 & -1.15 & 0.252 & & \\
\hline & U_Fi & 0.32 & 0.21 & 1.54 & 0.126 & & \\
\hline & U_Fr & 0.37 & 0.27 & 1.35 & 0.179 & & \\
\hline & U_Sg & -0.16 & 0.27 & -0.60 & 0.552 & & \\
\hline & U_Sg_Fi & -0.38 & 0.27 & -1.38 & 0.168 & & \\
\hline
\end{tabular}

a $\mathrm{G}$ CC = grazed control, G_Fg = grazed + fall glyphosate, G_Fi = grazed + fall imazapic, U_Fg = ungrazed + fall glyphosate, U_Fi = ungrazed + fall imazapic, U_Fr = ungrazed + fall rimsulfuron, U_Sg = ungrazed + spring glyphosate, $\mathrm{U}_{-} \mathrm{Sg}$ _Fi $=$ ungrazed + spring glyphosate + fall imazapic. ${ }^{\mathrm{b}}$ Bold values indicate significance at a $p$ value of $<0.05 .{ }^{*}=$ significance at $p$ value of $<0.10 .{ }^{c}$ Pre-treatment amount of Bromus tectorum from May sampling in the respective year.

Table 4. The response of Bromus tectorum seed production to grazing and/or herbicide treatments, analyzed using a linear mixed effects model. All treatments (parameters) are with respect to the ungrazed control treatment (U_C), which is the intercept in the model. In 2015 only the grazed (G) and ungrazed control, and the spring applied herbicide treatment results are shown, because fall herbicide application had not yet occurred. Results are based on log transformed B. tectorum seed production.

\begin{tabular}{|c|c|c|c|c|c|c|c|}
\hline \multicolumn{2}{|c|}{ Fixed Effects } & \multirow[b]{2}{*}{ Estimate } & \multirow[b]{2}{*}{ SE } & \multirow[b]{2}{*}{$t$ Value } & \multirow[b]{2}{*}{$\operatorname{Pr}(>|t|)^{b}$} & \multicolumn{2}{|c|}{ Random Effects } \\
\hline Year & Parameter $^{a}$ & & & & & Group & Variance \\
\hline \multirow[t]{5}{*}{2015} & Intercept & 0.67 & 0.19 & 3.49 & 0.002 & pBROTE $^{c}$ & 0.72 \\
\hline & G_C & 0.31 & 0.16 & 1.92 & 0.057 * & Frame/Rep & 0.00 \\
\hline & U_Sg & -0.87 & 0.26 & -3.40 & 0.001 & $\operatorname{Rep}$ & 0.00 \\
\hline & & & & & & Location & 0.05 \\
\hline & & & & & & Residual & 0.78 \\
\hline \multirow{10}{*}{2016} & Intercept & 1.59 & 0.44 & 3.61 & 0.003 & pBROTE & 1.0 \\
\hline & G_C & 0.37 & 0.46 & 0.80 & 0.43 & Frame/Rep & 0.00 \\
\hline & G_Fg & 0.50 & 0.41 & 1.21 & 0.23 & Rep & 0.24 \\
\hline & G_Fi & -0.08 & 0.43 & -0.19 & 0.85 & Location & 0.54 \\
\hline & G_Fr & 0.16 & 0.44 & 0.37 & 0.72 & Residual & 1.05 \\
\hline & U_Fg & -0.00 & 0.51 & -0.01 & 0.99 & & \\
\hline & U_Fi & 0.20 & 0.42 & 0.47 & 0.64 & & \\
\hline & U_Fr & 0.75 & 0.54 & 1.41 & 0.16 & & \\
\hline & U_Sg & 0.09 & 0.54 & 0.16 & 0.87 & & \\
\hline & U_Sg_Fi & 0.43 & 0.53 & 0.81 & 0.42 & & \\
\hline \multirow[t]{6}{*}{2017} & Intercept & 2.30 & 0.43 & 5.38 & $<0.001$ & Frame/Rep & 0.00 \\
\hline & G_C & -0.38 & 0.33 & -1.15 & 0.251 & Rep & 0.20 \\
\hline & G_Fg & -0.28 & 0.33 & -0.86 & 0.394 & Location & 0.70 \\
\hline & G_Fi & -0.62 & 0.33 & -1.87 & 0.065 * & Residual & 0.93 \\
\hline & G_Fr & -0.12 & 0.33 & -0.37 & 0.715 & & \\
\hline & U_Fg & -0.68 & 0.41 & -1.65 & 0.102 & & \\
\hline
\end{tabular}


Table 4. Cont.

\begin{tabular}{cccccccc}
\hline \multicolumn{2}{c}{ Fixed Effects } & \multicolumn{1}{c}{ Random Effects } \\
\hline Year & Parameter $^{\mathbf{a}}$ & Estimate & SE & $\boldsymbol{t}$ Value & $\operatorname{Pr}(>|\mathbf{t}|)^{\mathbf{b}}$ & Group & Variance \\
\hline 2017 & U_Fi & 0.42 & 0.33 & 1.28 & 0.204 & & \\
& U_Fr & 0.62 & 0.41 & 1.51 & 0.133 & & \\
& U_Sg & -0.09 & 0.41 & -0.21 & 0.831 & & \\
& U_Sg_Fi & -0.09 & 0.41 & -0.22 & 0.829 & & \\
\hline
\end{tabular}

a G_C $_{-}$grazed control, G_Fg = grazed + fall glyphosate, G_Fi = grazed + fall imazapic, U_Fg = ungrazed + fall glyphosate, U_Fi = ungrazed + fall imazapic, U_Fr = ungrazed + fall rimsulfuron, U_Sg = ungrazed + spring glyphosate, $\mathrm{U}_{-} \mathrm{Sg}$ _Fi $=$ ungrazed + spring glyphosate + fall imazapic. ${ }^{\mathrm{b}}$ Bold values indicate significance at a $p$ value of $<0.05 .{ }^{*}=$ significance at $p$ value of $<0.10$. ${ }^{c}$ Pre-treatment amount of Bromus tectorum from May sampling in the respective year.
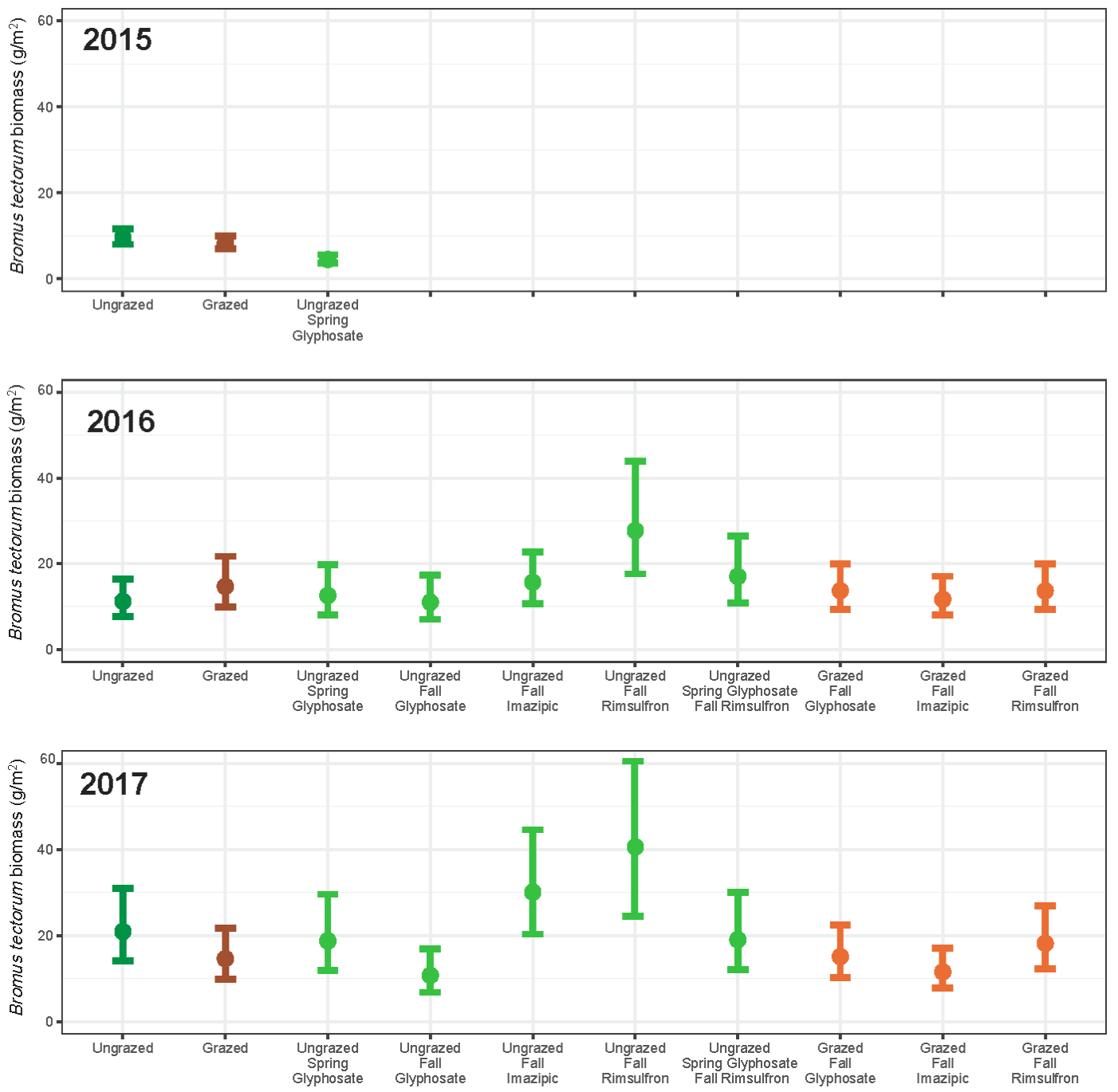

Figure 1. Fitted model results for Bromus tectorum biomass ( $g$; mean $\pm \mathrm{SE}$ ) response to grazing, herbicide and integrated treatments at Red Bluff, Montana in 2015, 2016, and 2017. Fall herbicide treatments were implemented after the summer data collection in 2015, so these treatments do not show results in 2015. Furthermore, fall herbicide results in 2016 and 2017 represent treatments implemented in the prior years. Data shown are predicted values from linear mixed effects models, and thus the means are not identical to means from the raw data. 

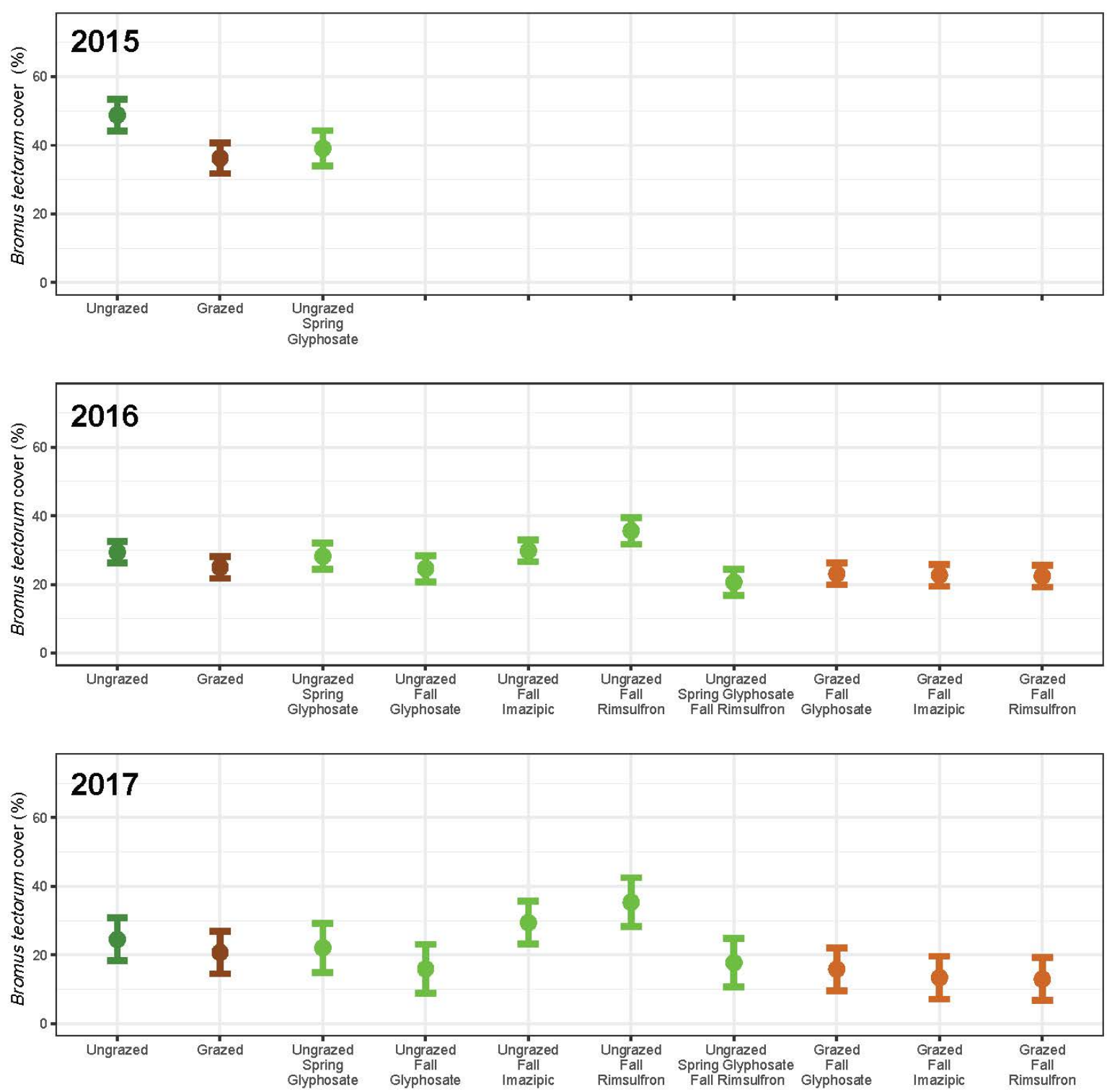

Figure 2. Fitted model results for Bromus tectorum cover (\%; mean $\pm \mathrm{SE}$ ) response to grazing, herbicide and integrated treatments at Red Bluff, Montana in 2015, 2016, and 2017. Fall herbicide treatments were implemented after summer data collection in 2015, so these treatments do not show results in 2015. Furthermore, fall herbicide results in 2016 and 2017 represent treatments implemented in the prior years. Data shown are predicted values from linear mixed effects models, and thus the means are not identical to means from the raw data. 

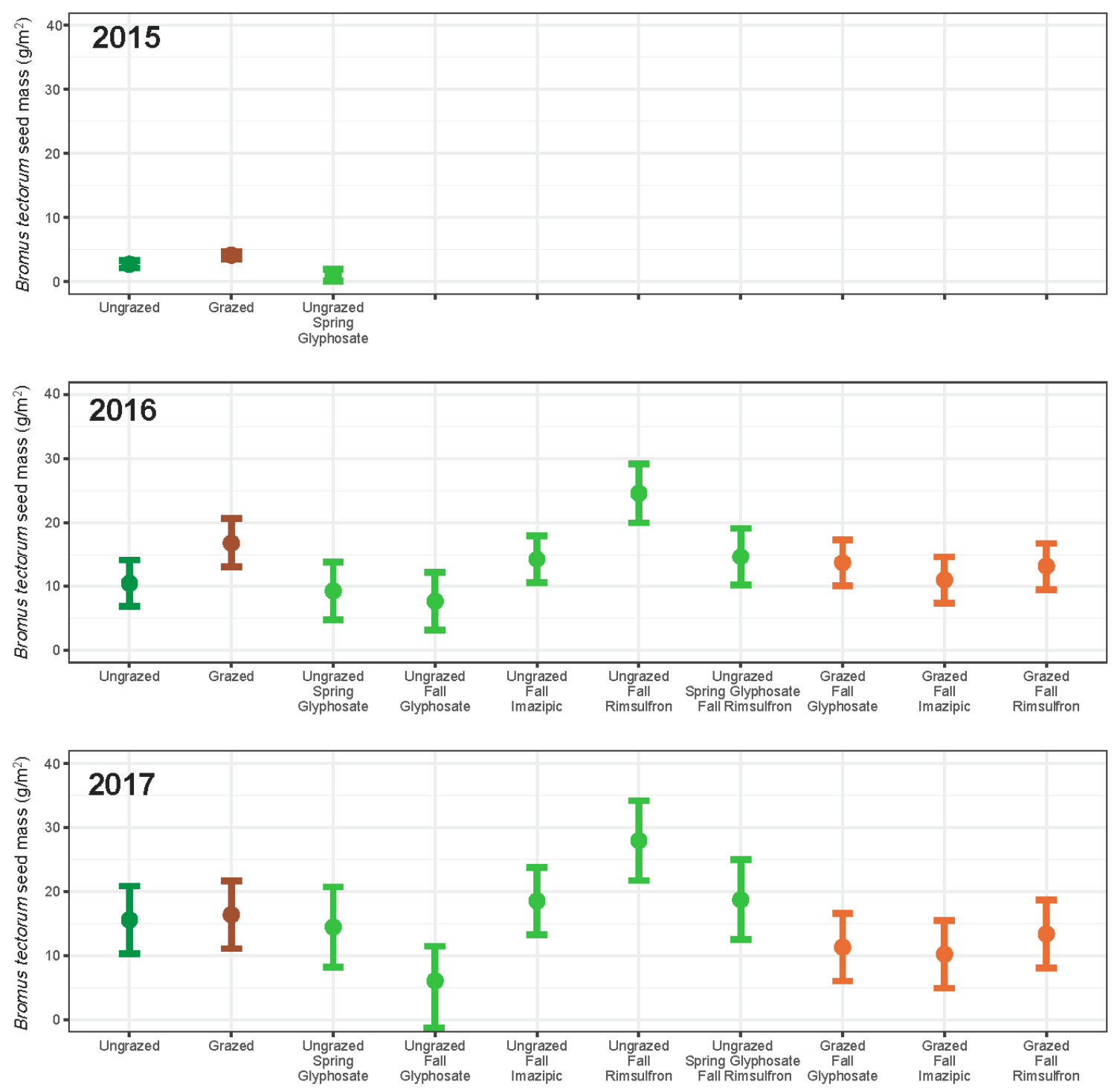

Figure 3. Fitted model results for Bromus tectorum seed weight (g; mean $\pm \mathrm{SE}$ ) response to grazing, herbicide and integrated treatments at Red Bluff, Montana in 2015, 2016, and 2017. Fall herbicide treatments were implemented after the summer data collection in 2015, so these treatments do not show results in 2015. Furthermore, fall herbicide results in 2016 and 2017 represent treatments implemented in the prior years. Data shown are predicted values from linear mixed effects models, and thus the means are not identical to means from the raw data.

Total plant cover, excluding B. tectorum, did not differ between grazed controls (i.e., grazed but no herbicide treatment) and ungrazed controls in years when grazing occurred (2015 and 2016); however, total plant cover increased to $32 \%$ in 2017 in previously grazed plots compared with $22 \%$ cover in ungrazed control plots (Table 5; Figure 4). Forb cover was greater in grazed only plots each year (Table 6; Figure 5), and generally accounted for the increase in total plant cover. Native grass cover was reduced from $11 \%$ to $7 \%$ and $11 \%$ to $6 \%$ in 2015 and 2016, respectively, in the plots that were grazed and had no herbicide application compared to the ungrazed control, but in 2017 native grass cover in grazed plots increased and was similar to the ungrazed plots with no herbicide application (Table 7; Figure 6). Short duration, intensive grazing may reduce perennial grass cover and potentially favor forbs in semi-arid systems [41,42], while light grazing, even for several years may not reduce the cover of perennial grasses in the sagebrush steppe [40]. Our results indicate that native grass cover rebounded within a year after intensive, short duration, grazing. 
Table 5. The response of total plant cover to grazing and/or herbicide treatments, analyzed using a linear mixed effects model. All treatments (parameters) are with respect to the ungrazed control treatment (U_C), which is the intercept in the model. In 2015 only the grazed (G) and ungrazed control, and the spring applied herbicide treatment results are shown, because fall herbicide application had not yet occurred. Results are based on log transformed total plant cover.

\begin{tabular}{|c|c|c|c|c|c|c|c|}
\hline \multicolumn{2}{|c|}{ Fixed Effects } & \multirow[b]{2}{*}{ Estimate } & \multirow[b]{2}{*}{ SE } & \multirow[b]{2}{*}{$t$ Value } & \multirow[b]{2}{*}{$\operatorname{Pr}(>|t|)^{b}$} & \multicolumn{2}{|c|}{ Random Effects } \\
\hline Year & Predictor $^{a}$ & & & & & Group & Variance \\
\hline \multirow[t]{4}{*}{2015} & Intercept & 2.92 & 0.20 & 14.7 & $<0.001$ & Frame/Rep & 0.00 \\
\hline & G_C & 0.00 & 0.11 & 0.01 & 0.993 & Rep & 0.34 \\
\hline & U_Sg & -0.07 & 0.17 & -0.43 & 0.665 & Location & 0.26 \\
\hline & & & & & & Residual & 0.79 \\
\hline \multirow[t]{10}{*}{2016} & Intercept & 3.00 & 0.23 & 13.2 & $<0.001$ & Frame/Rep & 0.00 \\
\hline & G_C & 0.10 & 0.14 & 0.70 & 0.485 & Rep & 0.17 \\
\hline & G_Fg & 0.09 & 0.14 & 0.61 & 0.542 & Location & 0.39 \\
\hline & G_Fi & -0.02 & 0.14 & -0.13 & 0.896 & Residual & 0.58 \\
\hline & G_Fr & -0.07 & 0.14 & -0.47 & 0.637 & & \\
\hline & U_Fg & 0.43 & 0.18 & 2.35 & 0.020 & & \\
\hline & U_Fi & -0.07 & 0.14 & -0.50 & 0.616 & & \\
\hline & U_Fr & 0.14 & 0.18 & 0.79 & 0.432 & & \\
\hline & U_Sg & 0.25 & 0.18 & 1.34 & 0.180 & & \\
\hline & U_Sg_Fi & 0.23 & 0.18 & 1.24 & 0.216 & & \\
\hline \multirow[t]{10}{*}{2017} & Intercept & 2.94 & 0.14 & 20.4 & $<0.001$ & Frame/Rep & 0.00 \\
\hline & G_C & 0.58 & 0.12 & 5.03 & $<0.001$ & Rep & 0.10 \\
\hline & G_Fg & 0.63 & 0.12 & 5.48 & $<0.001$ & Location & 0.23 \\
\hline & G_Fi & 0.57 & 0.12 & 4.95 & $<0.001$ & Residual & 0.46 \\
\hline & G_Fr & 0.62 & 0.12 & 5.34 & $<0.001$ & & \\
\hline & U_Fg & 0.48 & 0.14 & 3.35 & $<0.001$ & & \\
\hline & U_Fi & 0.45 & 0.12 & 3.95 & $<0.001$ & & \\
\hline & U_Fr & 0.41 & 0.14 & 2.88 & $<0.001$ & & \\
\hline & U_Sg & 0.26 & 0.14 & 1.80 & 0.073 * & & \\
\hline & U_Sg_Fi & 0.48 & 0.14 & 3.34 & $<0.001$ & & \\
\hline
\end{tabular}

${ }^{a}$ G_C = grazed control, G_Fg = grazed + fall glyphosate, G_Fi = grazed + fall imazapic, U_Fg = ungrazed + fall glyphosate, U_Fi = ungrazed + fall imazapic, U_Fr = ungrazed + fall rimsulfuron, U_Sg = ungrazed + spring glyphosate, U_Sg_Fi $=$ ungrazed + spring glyphosate + fall imazapic. ${ }^{b}$ Bold values indicate significance at a $p$ value of $<0.05{ }^{*}=$ significance at $p$ value of $<0.10$. 

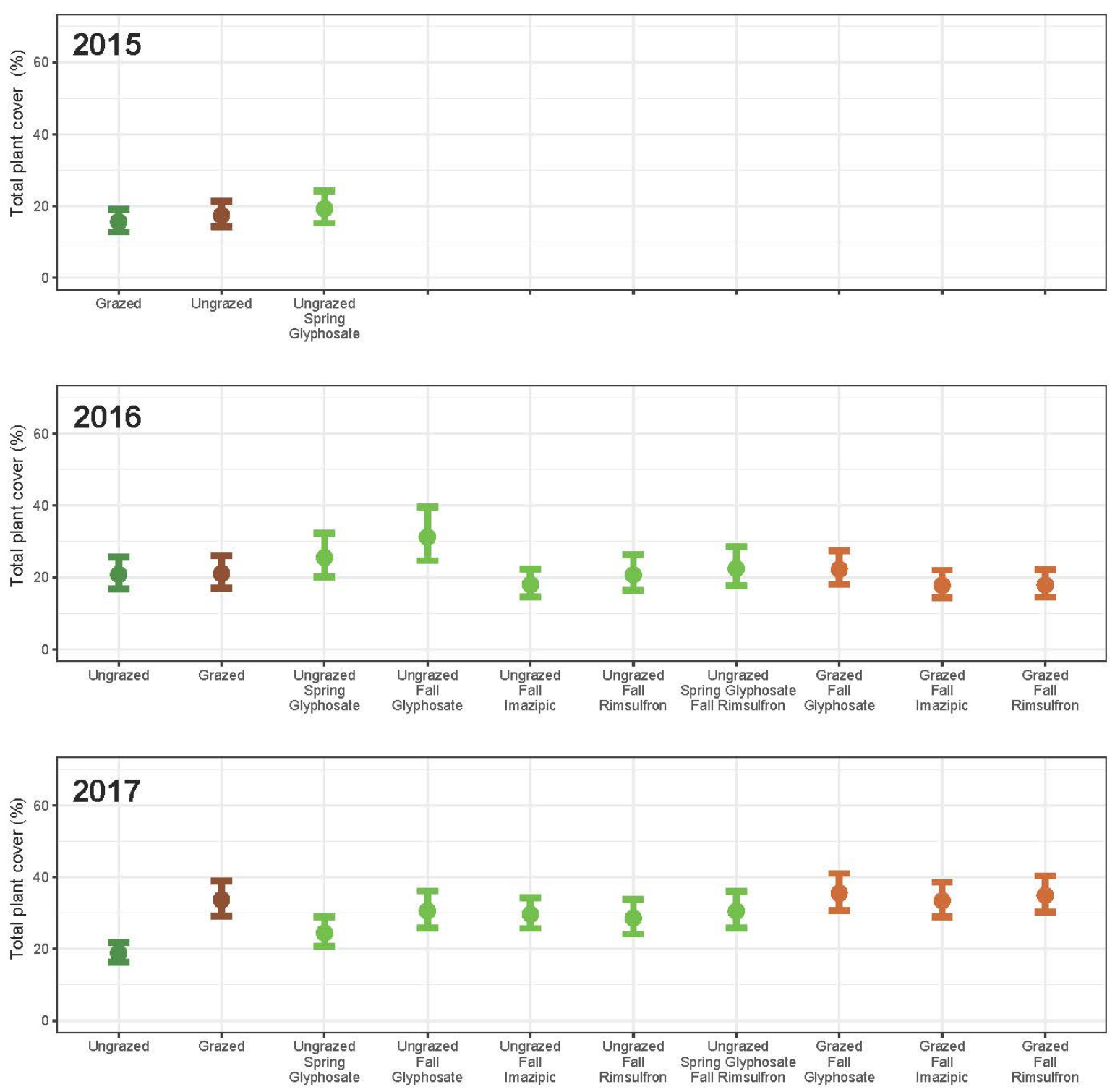

Figure 4. Fitted model results for total plant cover (excluding Bromus tectorum; \%; mean \pm SE) response to grazing, herbicide, and integrated treatments at Red Bluff, Montana in 2015, 2016, and 2017. Fall herbicide treatments were implemented after summer data collection in 2015, so these treatments do not show results in 2015. Furthermore, fall herbicide results in 2016 and 2017 represent treatments implemented in the prior years. Data shown are predicted values from linear mixed effects models, and thus the means are not identical to means from the raw data. 

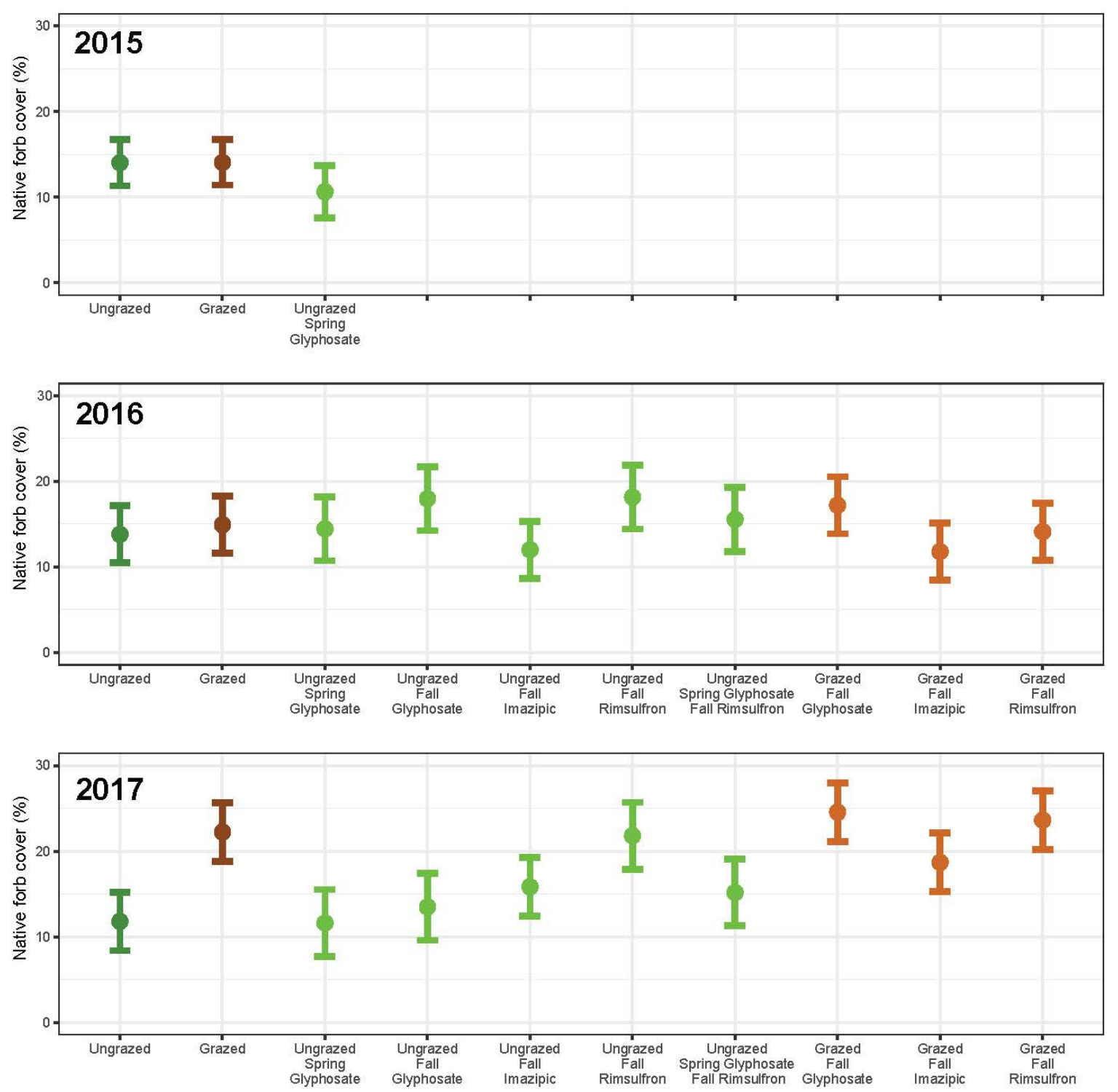

Figure 5. Fitted model results for forb cover (\%; mean $\pm \mathrm{SE}$ ) response to grazing, herbicide, and integrated treatments at Red Bluff, Montana in 2015, 2016, and 2017. Fall herbicide treatments were implemented after summer data collection in 2015, so these treatments do not show results in 2015. Furthermore, fall herbicide results in 2016 and 2017 represent treatments implemented in the prior years. Data shown are predicted values from linear mixed effects models, and thus the means are not identical to means from the raw data. 

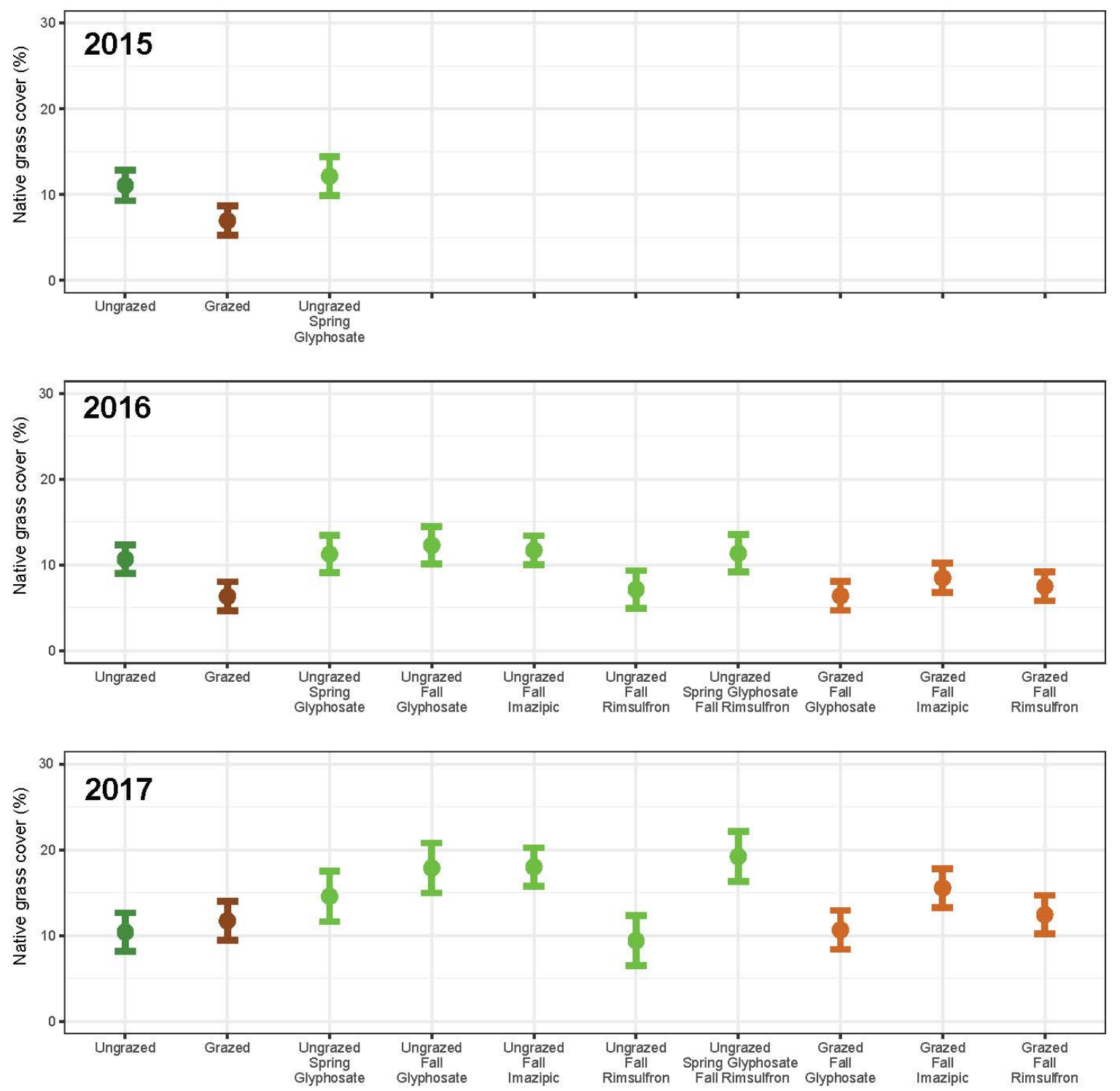

Figure 6. Fitted model results for native grass cover (\%; mean $\pm \mathrm{SE}$ ) response to grazing, herbicide, and integrated treatments at Red Bluff, Montana in 2015, 2016, and 2017. Fall herbicide treatments were implemented after summer data collection in 2015, so these treatments do not show results in 2015. Furthermore, fall herbicide results in 2016 and 2017 represent treatments implemented in the prior years. Data shown are predicted values from linear mixed effects models, and thus the means are not identical to means from the raw data.

\subsection{Herbicide}

Herbicide application in ungrazed plots had minimal impact on B. tectorum biomass, cover or seed production in any year compared to ungrazed plots that did not receive any herbicide treatment (Tables 2-4, Figures 1-3). Spring glyphosate application in 2015 reduced biomass and cover of B. tectorum by $3 \%$ and $15 \%$, respectively. Neither glyphosate nor imazapic applied in the fall reduced B. tectorum biomass, cover, or seed production in any subsequent year, except in 2016 when ungrazed plots treated with glyphosate in the spring and imazapic the previous fall (2015) had lower B. tectorum cover $(9 \%)$ than ungrazed control plots (28\%). One notable undesired result of herbicide treatment was that ungrazed plots treated with fall rimsulfuron tended to have higher B. tectorum biomass (14 g and $28 \mathrm{~g}$ higher in 2016 and 2017, respectively) than untreated control plots, although the 2017 result was not significant ( $p=0.091$, Table 2). These results, showing that herbicides had minimal effect on B. tectorum, 
highlight the inconsistency in the ability of herbicides to reduce $B$. tectorum abundance, especially with only limited herbicide application (two years for spring glyphosate but only one year for fall applications due to low fall germination in 2016). Previous studies have measured the effective control of $B$. tectorum via imazapic [28,29,43,44] and rimsulfuron [30,45], although a review of imazapic efficacy studies $(n=24)$ in Montana showed effective but variable results, with one year of application [29].

Glyphosate was not effective in our study in contrast to Espeland [27] and Morris [11], which may be attributed to the abundant $B$. tectorum seedbank at our site, where $B$. tectorum had been the dominant species since the fire break was established in 2012 [35] and no control action had been implemented. Bromus tectorum, which is capable of both fall and spring germination [46], may have emerged after herbicide application. Spring precipitation is vital for B. tectorum growth [47], and abundant spring precipitation at the site (mean March-May for study period $=21.6 \mathrm{~cm}$ ) [48] could have promoted B. tectorum germination, and provided ample moisture for growth of plants surviving either the spring or the previous fall herbicide treatments. Further, late spring recruits could offset earlier losses [46], such that treated B. tectorum populations could produce similar biomass, cover, and seeds to the untreated population even after the spring glyphosate application.

Glyphosate applied in the fall, but not the spring, increased total plant cover (excluding B. tectorum) in 2016. Furthermore, all fall-applied herbicides (glyphosate, imazapic, and rimsulfuron), as well as spring glyphosate + fall imazapic, increased total plant cover in 2017, two years after herbicide treatment, compared to ungrazed controls (Table 5; Figure 4). Similarly, fall-applied herbicides generally increased forb cover, with the exception of fall imazapic in 2016 and fall glyphosate in 2017, which did not alter forb cover (Table 6; Figure 5). Spring glyphosate alone did not alter forb cover, but forb cover was slightly higher in spring glyphosate + fall imazapic plots in 2017.

Table 6. The response of forb cover to grazing and/or herbicide treatments, analyzed using a linear mixed effects model. All treatments (parameters) are with respect to the ungrazed control treatment (U_C), which is the intercept in the model. In 2015 only the grazed (G) and ungrazed control, and the spring applied herbicide treatment results are shown, because fall herbicide application had not yet occurred. Results are based on log transformed forb cover.

\begin{tabular}{|c|c|c|c|c|c|c|c|}
\hline \multicolumn{2}{|c|}{ Fixed Effects } & \multirow[b]{2}{*}{ Estimate } & \multirow[b]{2}{*}{ SE } & \multirow[b]{2}{*}{$t$ Value } & \multirow[b]{2}{*}{$\operatorname{Pr}(>|t|)^{b}$} & \multicolumn{2}{|c|}{ Random Effects } \\
\hline Year & Parameter $^{a}$ & & & & & Group & Variance \\
\hline \multirow[t]{4}{*}{2015} & Intercept & 2.18 & 0.30 & 7.17 & 0.002 & Frame/Rep & 0.00 \\
\hline & G_C & 0.35 & 0.12 & 2.86 & 0.005 & Rep & 0.33 \\
\hline & U_Sg & -0.18 & 0.19 & -0.98 & 0.330 & Location & 0.53 \\
\hline & & & & & & Residual & 0.88 \\
\hline \multirow[t]{10}{*}{2016} & Intercept & 2.29 & 0.38 & 6.10 & 0.004 & Frame/Rep & 0.00 \\
\hline & G_C & 0.47 & 0.19 & 2.51 & 0.013 & Rep & 0.28 \\
\hline & G_Fg & 0.47 & 0.19 & 2.52 & 0.012 & Location & 0.67 \\
\hline & G_Fi & -0.11 & 0.19 & -0.59 & 0.555 & Residual & 0.74 \\
\hline & G_Fr & 0.08 & 0.19 & 0.40 & 0.688 & & \\
\hline & U_Fg & 0.45 & 0.24 & 1.86 & $0.064 *$ & & \\
\hline & U_Fi & -0.23 & 0.19 & -1.23 & 0.222 & & \\
\hline & U_Fr & 0.51 & 0.24 & 2.13 & 0.035 & & \\
\hline & U_Sg & 0.40 & 0.24 & 1.67 & $0.096^{*}$ & & \\
\hline & U_Sg_Fi & 0.25 & 0.24 & 1.04 & 0.301 & & \\
\hline \multirow[t]{8}{*}{2017} & Intercept & 2.06 & 0.27 & 7.57 & 0.001 & Frame/Rep & 0.00 \\
\hline & G_C & 1.05 & 0.17 & 6.19 & $<0.001$ & Rep & 0.17 \\
\hline & G_Fg & 1.18 & 0.17 & 6.95 & $<0.001$ & Location & 0.47 \\
\hline & G_Fi & 0.65 & 0.17 & 3.83 & 0.002 & Residual & 0.68 \\
\hline & G_Fr & 0.96 & 0.17 & 5.65 & $<0.001$ & & \\
\hline & U_Fg & 0.36 & 0.21 & 1.69 & 0.092 * & & \\
\hline & U_Fi & 0.35 & 0.17 & 2.05 & 0.042 & & \\
\hline & U_Fr & 0.95 & 0.21 & 4.46 & $<0.001$ & & \\
\hline
\end{tabular}


Table 6. Cont.

\begin{tabular}{cccccccc}
\hline \multicolumn{2}{c}{ Fixed Effects } & \multicolumn{1}{c}{ Random Effects } \\
\hline Year & Parameter $^{\mathbf{a}}$ & Estimate & SE & $\boldsymbol{t}$ Value & $\operatorname{Pr}(>|\mathbf{t}|)^{\mathbf{b}}$ & Group & Variance \\
\hline 2017 & U_Sg & 0.27 & 0.21 & 1.27 & 0.207 & & \\
& U_Sg_Fi & 0.44 & 0.21 & 2.06 & $\mathbf{0 . 0 4 1}$ & & \\
\hline
\end{tabular}

a ${ }_{-} C$ = grazed control, G_Fg = grazed + fall glyphosate, G_Fi = grazed + fall imazapic, U_Fg = ungrazed + fall glyphosate, U_Fi = ungrazed + fall imazapic, U_Fr = ungrazed + fall rimsulfuron, U_Sg = ungrazed + spring glyphosate, $\mathrm{U}_{-} \mathrm{Sg}$ _Fi $=$ ungrazed + spring glyphosate + fall imazapic. ${ }^{\mathrm{b}}$ Bold values indicate significance at a $p$ value of $<0.05 .{ }^{*}=$ significance at $p$ value of $<0.10$.

Native grass cover was not affected by any herbicide treatment on the ungrazed plots during treatment years (2015 or 2016), but plots treated with fall glyphosate, fall imazapic, and spring glyphosate + fall imazapic increased native grass cover by $7 \%, 8 \%$, and $10 \%$, respectively, compared with the control in 2017 (Table 7; Figure 6). These results differ from those of Baker et al. [44] who determined that imazapic ( $175 \mathrm{~g}$ a.i. $\mathrm{ha}^{-1}$ ) reduced both forbs and native grasses in Wyoming big sagebrush habitat. However, our results are supported by Wallace et al. [49] who determined that imazapic and rimsulfuron had negligible effects on Pseudoroegneria spicata and Thinopyrum intermedium when used to treat Ventenata dubia. Nonetheless, while native grasses were not damaged in our study, similar to Elseroad et al. [43], our results indicate that herbicide application alone does not effectively increase native perennial grasses through the reduction of annual grasses. Multiple years of herbicide application may be needed to measure positive changes in perennial grass cover. However, at our site fall application was not advisable in the second year due to sparse vegetation cover in late fall.

Table 7. The response of native grass cover to grazing and/or herbicide treatments, analyzed using a linear mixed effects model. All treatments (parameters) are with respect to the ungrazed control treatment (U_C), which is the intercept in the model. In 2015 only the grazed (G) and ungrazed control, and the spring applied herbicide treatment results are shown, because fall herbicide application had not yet occurred. Results are based on log transformed native grass cover.

\begin{tabular}{|c|c|c|c|c|c|c|c|}
\hline \multicolumn{2}{|c|}{ Fixed Effects } & \multirow[b]{2}{*}{ Estimate } & \multirow[b]{2}{*}{ SE } & \multirow[b]{2}{*}{$t$ Value } & \multirow[b]{2}{*}{$\operatorname{Pr}(>|t|)^{b}$} & \multicolumn{2}{|c|}{ Random Effects } \\
\hline Year & Parameter $^{a}$ & & & & & Group & Variance \\
\hline \multirow[t]{4}{*}{2015} & Intercept & 11.2 & 1.62 & 6.90 & $<0.001$ & Frame/Rep & 0.00 \\
\hline & G_C & -4.18 & 1.29 & -3.25 & 0.001 & Rep & 2.62 \\
\hline & U_Sg & 0.05 & 1.95 & 0.02 & 0.981 & Location & 1.81 \\
\hline & & & & & & Residual & 9.35 \\
\hline \multirow[t]{10}{*}{2016} & Intercept & 10.7 & 1.69 & 6.32 & $<0.001$ & Frame/Rep & 0.00 \\
\hline & G_C & -4.16 & 1.93 & -2.15 & 0.032 & Rep & 0.88 \\
\hline & G_Fg & -4.37 & 1.93 & -2.26 & 0.025 & Location & 1.91 \\
\hline & G_Fi & -1.65 & 1.93 & -0.85 & 0.395 & Residual & 7.70 \\
\hline & G_Fr & -3.12 & 1.93 & -1.61 & 0.108 & & \\
\hline & U_Fg & 1.39 & 2.38 & 0.59 & 0.559 & & \\
\hline & U_Fi & 1.31 & 1.93 & 0.68 & 0.496 & & \\
\hline & U_Fr & -2.92 & 2.38 & -1.23 & 0.220 & & \\
\hline & U_Sg & 0.58 & 2.38 & 0.24 & 0.808 & & \\
\hline & U_Sg_Fi & 1.14 & 2.38 & 0.48 & 0.632 & & \\
\hline \multirow[t]{8}{*}{2017} & Intercept & 10.4 & 2.26 & 4.61 & $<0.001$ & Frame/Rep & 0.00 \\
\hline & G_C & 1.31 & 2.45 & 0.54 & 0.593 & Rep & 2.47 \\
\hline & G_Fg & 0.25 & 2.45 & 0.10 & 0.920 & Location & 2.32 \\
\hline & G_Fi & 5.14 & 2.45 & 2.10 & 0.037 & Residual & 9.76 \\
\hline & G_Fr & 2.03 & 2.45 & 0.83 & 0.408 & & \\
\hline & U_Fg & 7.47 & 3.06 & 2.44 & 0.015 & & \\
\hline & U_Fi & 7.59 & 2.44 & 3.11 & 0.002 & & \\
\hline & U_Fr & -1.0 & 3.06 & -0.33 & 0.745 & & \\
\hline
\end{tabular}


Table 7. Cont.

\begin{tabular}{cccccccc}
\hline \multicolumn{2}{c}{ Fixed Effects } & \multicolumn{1}{c}{ Random Effects } \\
\hline Year & Parameter $^{\mathbf{a}}$ & Estimate & SE & $\boldsymbol{t}$ Value & $\operatorname{Pr}(>|\mathbf{t}|)$ & Group & Variance \\
\hline 2017 & U_Sg & 4.16 & 3.06 & 1.36 & 0.176 & & \\
& U_Sg_Fi & 8.81 & 3.06 & 2.88 & $\mathbf{0 . 0 0 4}$ & & \\
\hline
\end{tabular}

a $\mathrm{G}$ C = grazed control, G_Fg = grazed + fall glyphosate, G_Fi = grazed + fall imazapic, U_Fg = ungrazed + fall glyphosate, U_Fi = ungrazed + fall imazapic, U_Fr = ungrazed + fall rimsulfuron, U_Sg = ungrazed + spring glyphosate, $\mathbf{U} \_\mathrm{Sg}$ _Fi $=$ ungrazed + spring glyphosate + fall imazapic. ${ }^{\mathrm{b}}$ Bold values indicate significance at a $p$ value of $<0.05 .{ }^{*}=$ significance at $p$ value of $<0.10$.

\subsection{Integrated Grazing and Herbicide}

Integrating grazing and herbicide did not improve B. tectorum management during treatment years compared to the ungrazed control plots; no integrated treatments reduced B. tectorum biomass, cover, or seed production in 2016, presumably due to a large annual grass seedbank, which takes several seasons to diminish. However, by 2017 some positive impacts were observed, and B. tectorum cover was less in grazed plots treated with imazapic or rimsulfuron than in ungrazed control plots (Table 3; Figure 2). Furthermore, grazed plots treated in the fall of 2015, and grazed plus imazapic or rimsulfuron plots had lower B. tectorum biomass in 2017 and cover in both 2016 and 2017 (Tables 2 and 3, Figures 1 and 2) than the respective herbicide treated but ungrazed plots. Similarly, in 2017, one year after the last grazing treatments were applied, B. tectorum seed production was less in grazed $(11.2 \mathrm{~g})$ plots treated with fall imazapic compared to ungrazed $(18.5 \mathrm{~g})$ fall imazapic plots (Table 4, Figure 3). These results indicate that integrated management of $B$. tectorum with herbicide and grazing could provide a level of control greater than herbicide or grazing alone. Diamond et al. [32] determined that the combination of intensive, short-term grazing, and prescribed burning reduced B. tectorum cover more than either treatment independently. Success was attributed to intensive grazing reducing B. tectorum biomass and reducing reproductive potential while prescribed burning killed seeds in the litter. The benefit of integrated management was also noted by Whitson and Koch [50] who determined that glyphosate $\left(0.55 \mathrm{~kg} \mathrm{ha}^{-1}\right)$ provided better control of $B$. tectorum when combined with intensive cattle grazing. Similarly, our integrated treatments were more successful than individual treatments likely because grazing removed biomass and then fall-applied herbicides not only limited growth but also minimized further seedling emergence.

The combination of grazing and herbicide had minimal impact on total plant, forb, or native grass cover in 2016: A few grazed treatments had slightly less cover than their respective ungrazed treatments (Tables 5-7; Figures 4-6). All treatments had higher total plant cover (excluding B. tectorum) than the ungrazed control in 2017 except ungrazed spring glyphosate, and there were no differences between grazed and ungrazed herbicide plots. For native grasses, cover was lower in grazed fall glyphosate plots compared to the respective ungrazed plots in both 2016 (6\% vs. 12\%) and 2017 $(10 \%$ vs. $18 \%)$, but there were no other differences (Figure 6). Forb cover differences were minimal between ungrazed and grazed herbicide treatments: Forb cover in 2016 was lower in grazed fall rimsulfuron plots than respective ungrazed plots (13\% vs. 19\%) and conversely in 2017 when it was lower in ungrazed fall glyphosate plots compared to grazed ones ( $14 \%$ vs $23 \%$; Figure 5). Overall, these results indicate that integrating grazing with some herbicides (imazapic and rimsulfuron) can have a positive effect on $B$. tectorum management and is not detrimental to native grasses or forbs, with the exception of integration of grazing and fall glyphosate, which reduced native grasses and increased forbs.

\subsection{Community Change}

Despite the slight improvements of integrated management over either grazing or herbicide alone, no treatments provided adequate control of $B$. tectorum, nor did they substantially change the plant community. Non-metric multidimensional scaling analysis indicated that treatments led to different 
plant communities, although the $\mathrm{R}^{2}$ values were low and NMDS stress values were moderately high (Table 8), suggesting no strong conclusions can be made. While plant communities may have changed slightly within three years, the dominant species generally did not (Supplemental Table S1). Bromus tectorum was most often the dominant species (18 out of 23 treatment $\times$ year combinations) and was never lower in rank than second. Combined forbs were typically the second most abundant, and became the highest abundance in years when B. tectorum was second. The native grasses Pascopyrum smithii, Festuca idahoensis, Pseudoroegneria spicata, Hesperostipa comata, and Bouteloua gracilis were generally the next most abundant species. These results highlight not only the fact that $B$. tectorum is an incredibly challenging weed to manage, but also the difficulty of altering the plant community in an area that has transitioned to a novel state dominated by $B$. tectorum. The lack of substantial community change is not surprising over the short time frame of our study because, while we did repeat most treatments over two years, more years of treatment may be necessary to change the plant community $[51,52]$ from an altered state.

Table 8. Treatment effects on plant community structure. Results based on non-metric multidimensional scaling (NMDS) and the distance matrix of plant species abundances. Model summary is from the package "adonis" in R and stress is provided by the NMDS analysis.

\begin{tabular}{ccccccccc}
\hline Year & & DF & Sum of Squares & Mean Squares & F Model & $\boldsymbol{R}^{\mathbf{2}}$ & Pr $(>$ F) & NMDS Stress \\
\hline \multirow{2}{2}{2015} & Treatment & 2 & 1.35 & 0.67 & 5.6 & 0.04 & 1 & 0.24 \\
& Residuals & 253 & 30.7 & 0.12 & & 0.96 & & \\
& Total & 255 & 32.1 & & & 1.00 & & \\
\hline \multirow{2}{2}{2016} & Treatment & 9 & 3.13 & 0.35 & 2.27 & 0.08 & $<\mathbf{0 . 0 0 1}$ & 0.27 \\
& Residuals & 246 & 37.8 & 0.15 & & 0.92 & & \\
& Total & 255 & 40.9 & & & 1.00 & & \\
\hline \multirow{2}{2}{2017} & Treatment & 9 & 3.64 & 0.37 & 2.56 & 0.09 & $<0.001$ & 0.27 \\
& Residuals & 246 & 35.9 & 0.15 & & 0.91 & & \\
& Total & 255 & 39.2 & & & 1.00 & & \\
\hline
\end{tabular}

\section{Conclusions}

Overall, none of the single treatments adequately reduced B. tectorum or increased other vegetation. Two combinations of integrated grazing and herbicide, specifically grazing with fall-applied imazapic or rimsulfuron, provided better results than herbicide alone; however, there is only weak support for our hypothesis that integrated management would be superior to individual treatment methods. Our second hypothesis that total plant cover, forbs, and grasses would differ between treatments was partially supported, as grazing alone or with fall-applied herbicides tended to reduce native grass cover while increasing forb cover in the second year of the study. A positive result from this research is that the intensive treatments of grazing plus herbicide did not reduce cover of the desired species in the final year (one year after the last treatments had been implemented), indicating that continued management of $B$. tectorum may facilitate the increase other plant cover. The final hypothesis that different treatments would shift plant communities was weakly supported statistically, but $B$. tectorum was still the most or second most dominant species. These results highlight the difficulties in managing dense $B$. tectorum infestations with either traditional or integrated management but do provide some encouragement for the integrated grazing and herbicide approach. Future research should incorporate different timing, frequency and intensity of grazing [16], possibly also new herbicide chemistries such as indaziflam in areas not actively grazed [53], and longer-term application and monitoring of treatments. Effective, consistent, and long-term control of B. tectorum once it becomes abundant, often due to disturbances, is notoriously difficult. Overall, integrating grazing and herbicide shows some promise, but further research is needed to establish reliable practices across a range of sites.

Supplementary Materials: The following are available online at http://www.mdpi.com/2073-4395/9/6/315/s1, Table S1: Cumulative abundance, proportion and accumulated frequency of plant species in plots at Red Bluff, Montana for 2015, 2016 and 2017. 
Author Contributions: Conceptualization and methodology, E.A.L., L.J.R., J.M.M. and D.R.; Investigation, E.A.L., L.J.R., J.M.M., and T.S.; Data analysis, E.A.L. and L.J.R.; Writing, E.A.L., L.J.R., T.S., J.M.M. and D.R.

Funding: This research was funded by the Montana Noxious Weed Trust Fund, grant number 2015-010.

Acknowledgments: We thank J.T. Saunders for providing and managing sheep during the experiment. Thanks to many graduate and undergraduate students who helped with sampling, particularly Christian Larson, Kaylee Schmitz, David Duran, and Erik Friesenhahn. E.A.L., L.J.R. and J.M.M. are supported by the National Institute of Food and Agriculture, U.S. Department of Agriculture Hatch: NMLehnhoff-17H, MONB00363, MONB00359, respectively.

Conflicts of Interest: The authors declare no conflict of interest.

\section{References}

1. Hobbs, R.J.; Huenneke, L.F. Disturbance, diversity, and invasion: Implications for conservation. Conserv. Biol. 1992, 6, 324-337. [CrossRef]

2. D'Antonio, C.M.; Dudley, T.L.; Mack, R.N. Disturbance and biological invasions: Direct effects and feedbacks. In Ecosystems of Disturbed Ground; Walker, L.H., Ed.; Elsevier: New York, NY, USA, 1999; pp. 413-451.

3. Hobbs, R.J.; Arico, S.; Aronson, J.; Baron, J.S.; Bridgewater, P.; Cramer, V.A.; Epstein, P.R.; Ewel, J.J.; Klink, C.A.; Lugo, A.E.; et al. Novel ecosystems: Theoretical and management aspects of the new ecological world order. Glob. Ecol. Biogeogr. 2006, 15, 1-7. [CrossRef]

4. Miller, J.R.; Bestelmeyer, B.T. What's wrong with novel ecosystems, really? Restor. Ecol. 2016, 24, 577-582. [CrossRef]

5. Radosevich, S.R.; Holt, J.S.; Ghersa, C. Ecology of Weeds and Invasive Plants, 3rd ed.; Wiley: Hoboken, NJ, USA, 2007.

6. Davis, S.; Mangold, J.; Menalled, F.; Orloff, L.N.; Miller, Z.; Lehnhoff, E. A meta-analysis of canada thistle (Cirsium arvense) management. Weed Sci. 2018, 66, 548-557. [CrossRef]

7. Monaco, T.A.; Mangold, J.M.; Mealor, B.A.; Mealor, R.D.; Brown, C.S. Downy brome control and impacts on perennial grass abundance: A systematic review spanning 64 years. Rangel. Ecol. Manag. 2017, 70, 396-404. [CrossRef]

8. Rinella, M.J.; Maxwell, B.D.; Fay, P.K.; Weaver, T.; Sheley, R.L. Control effort exacerbates invasive-Species problem. Ecol. Appl. 2009, 19, 155-162. [CrossRef] [PubMed]

9. Bahm, M.A.; Barnes, T.G. Native grass and forb response to pre-emergent application of imazapic and imazapyr. Nat. Areas J. 2011, 31, 75-79. [CrossRef]

10. Beran, D.D.; Gaussoin, R.E.; Masters, R.A. Native wildflower establishment with imidazolinone herbicides. Hortscience 1999, 34, 283-286. [CrossRef]

11. Morris, C.; Morris, L.R.; Surface, C. Spring glyphosate application for selective control of downy brome (Bromus tectorum L.) on great basin rangelands. Weed Technol. 2016, 30, 297-302. [CrossRef]

12. Kettenring, K.M.; Adams, C.R. Lessons learned from invasive plant control experiments: A systematic review and meta-analysis. J. Appl. Ecol. 2011, 48, 970-979. [CrossRef]

13. Kleppel, G.S.; LaBarge, E. Using sheep to control purple loosestrife (Lythrum salicaria). Invasive Plant Sci. Manag. 2011, 4, 50-57. [CrossRef]

14. Goehring, B.J.; Launchbaugh, K.L.; Wilson, L.M. Late-season targeted grazing of yellow starthistle (Centaurea solstitialis) with goats in idaho. Invasive Plant Sci. Manag. 2010, 3, 148-154. [CrossRef]

15. James, J.J.; Davy, J.; Doran, M.P.; Becchetti, T.; Brownsey, P.; Laca, E.A. Targeted grazing impacts on invasive and native plant abundance change with grazing duration and stocking density. Rangel. Ecol. Manag. 2017, 70, 465-468. [CrossRef]

16. Rinella, M.J.; Hileman, B.J. Efficacy of prescribed grazing depends on timing intensity and frequency. J. Appl. Ecol. 2009, 46, 796-803. [CrossRef]

17. Liebman, M.; Mohler, C.L.; Staver, C.P. Ecological Management of Agricultural Weeds; Cambridge University Press: Cambridge, UK, 2001.

18. Lym, R.G. The biology and integrated management of leafy spurge (Euphorbia esula) on north dakota rangeland. Weed Technol. 1998, 12, 367-373. [CrossRef]

19. Sheley, R.L.; Jacobs, J.S.; Martin, J.M. Integrating 2,4-d and sheep grazing to rehabilitate spotted knapweed infestations. J. Range Manag. 2004, 57, 371-375. [CrossRef] 
20. Seefeldt, S.S.; Taylor, J.B.; Van Vleet, S. Reducing euphorbia esula with a combination of sheep grazing and imazapic. J. Arid. Environ. 2007, 69, 432-440. [CrossRef]

21. Taylor, K.; Brummer, T.; Rew, L.J.; Lavin, M.; Maxwell, B.D. Bromus tectorum response to fire varies with climate conditions. Ecosystems 2014, 17, 960-973. [CrossRef]

22. Mack, R.N. Invasion of Bromus tectorum L. Into western North America-An ecological chronicle. Agro-Ecosyst. 1981, 7, 145-165. [CrossRef]

23. Knapp, P.A. Cheatgrass (Bromus tectorum L.) dominance in the great basin desert-History, persistence, and influences to human activities. Glob. Environ. Chang. -Hum. Policy Dimens. 1996, 6, 37-52. [CrossRef]

24. Young, J.; Clements, D. Cheatgrass: Fire and Forage on the Range; University of Nevada Press: Reno, NV, USA, 2009.

25. Morrow, L.A.; Stahlman, P.W. The history and distribution of downy brome (Bromus tectorum) in North America. Weed Sci. 1984, 32, 2-6. [CrossRef]

26. Menalled, F.; Mangold, J.; Orloff, L.N.; Davis, E. Cheatgrass: Identification, Biology and Integrated Management; University, M.S., Ed.; Montana State University Extension: Bozeman, MT, USA, 2017; Volume MT200811AG.

27. Espeland, E.K.; Kilian, R. Low-dose glyphosate does not control annual bromes in the northern great plains. Invasive Plant Sci. Manag. 2015, 8, 334-340. [CrossRef]

28. Ehlert, K.A.; Engel, R.E.; Mangold, J.M. Imazapic activity in a semiarid climate in downy brome (Bromus tectorum)-infested rangeland and crp sites. Weed Technol. 2015, 29, 472-479. [CrossRef]

29. Mangold, J.; Parkinson, H.; Duncan, C.; Rice, P.; Davis, E.; Menalled, F. Downy brome (Bromus tectorum) control with imazapic on montana grasslands. Invasive Plant Sci. Manag. 2013, 6, 554-558. [CrossRef]

30. Kyser, G.B.; Wilson, R.G.; Zhang, J.M.; DiTomaso, J.M. Herbicide-assisted restoration of great basin sagebrush steppe infested with medusahead and downy brome. Rangel. Ecol. Manag. 2013, 66, 588-596. [CrossRef]

31. Burnett, S.A.; Mealor, B.A. Imazapic effects on competition dynamics between native perennial grasses and downy brome (Bromus tectorum). Invasive Plant Sci. Manag. 2015, 8, 72-80. [CrossRef]

32. Diamond, J.M.; Call, C.A.; Devoe, N. Effects of targeted grazing and prescribed burning on community and seed dynamics of a downy brome (Bromus tectorum)-dominated landscape. Invasive Plant Sci. Manag. 2012, 5, 259-269. [CrossRef]

33. USDA. Web Soil Survey. Available online: https://websoilsurvey.sc.egov.usda.gov/App/WebSoilSurvey.aspx (accessed on 1 March 2018).

34. Mueggler, W.F.; Stewart, W.L. Grassland and Shrubland Habitat Types of Western Montana; USDA Forest Serv Gen Tech Rep INT-166; U.S. Department of Agriculture: Ogden, UT, USA, 1980.

35. Seipel, T.; Rew, L.J.; Taylor, K.T.; Maxwell, B.D.; Lehnhoff, E.A. Disturbance type influences plant community resilience and resistance to Bromus tectorum invasion in the sagebrush steppe. Appl. Veg. Sci. 2018, 21, 385-394. [CrossRef]

36. Bates, D.; Baechler, M.; Bolker, B.; Walker, S. Fitting linear mixed-effects models using lme4. J. Stat. Softw. 2015, 67, 1-48. [CrossRef]

37. R Core Team. A Language and Environment for Statistical Computing; Foundation for Statistical Computing: Vienna, Austria, 2017.

38. Oksanen, J.; Guillaume Blanchet, F.; Friendly, M.; Kindt, R.; Legendre, P.; McGlinn, D.; Minchin, P.R.; O'Hara, R.B.; Simpson, G.L.; Solymos, P.; et al. Vegan: Community Ecology Package. 2019. R package version 2.5-4. Available online: https://CRAN.R-project.org/package=vegan (accessed on 1 March 2019).

39. Kindt, R.; Coe, R. Tree Diversity Analysis: A Manual and Software for Common Statistical Methods for Ecological and Biodiversity Studies; World Agroforestry Centre: Nairobi, Kenya, 2005.

40. Bates, J.D.; Davies, K.W. Cattle grazing and vegetation succession on burned sagebrush steppe. Rangel. Ecol. Manag. 2014, 67, 412-422. [CrossRef]

41. HilleRisLambers, J.; Yelenik, S.G.; Colman, B.P.; Levine, J.M. California annual grass invaders: The drivers or passengers of change? J. Ecol. 2010, 98, 1147-1156. [CrossRef] [PubMed]

42. Young, J.; Tipton, F.; McArthur, E.; Romney, E.; SMith, S. Invasion of cheatgrass into arid environments of the lahontan basin. In Proceedings of the Symposium on Cheatgrass Invasion, Shrub Die-Off, and Other Aspects of Shrub Biology and Management, Las Vegas, NV, USA, 5-7 April 1989; Intermountain Research Station, Forest Service, USDA: Las Vegas, NV, USA, 1990; pp. 37-40.

43. Elseroad, A.C.; Rudd, N.T. Can imazapic increase native species abundance in cheatgrass (Bromus tectorum) invaded native plant communities? Rangel. Ecol. Manag. 2011, 64, 641-648. [CrossRef] 
44. Baker, W.L.; Garner, J.; Lyon, P. Effect of imazapic on cheatgrass and native plants in wyoming big sagebrush restoration for gunnison sage-grouse. Nat. Areas J. 2009, 29, 204-209. [CrossRef]

45. Hirsch, M.C.; Monaco, T.A.; Ca, C.A.; Ransom, C.V. Comparison of herbicides for reducing annual grass emergence in two great basin soils. Rangel. Ecol. Manag. 2012, 65, 66-75. [CrossRef]

46. Mack, R.N.; Pyke, D.A. The demography of Bromus tectorum-Variation in time and space. J. Ecol. 1983, 71, 69-93. [CrossRef]

47. Bradford, J.B.; Lauenroth, W.K. Controls over invasion of Bromus tectorum: The importance of climate, soil, disturbance and seed availability. J. Veg. Sci. 2006, 17, 693-704.

48. U.S. Climate Data. Available online: https://www.usclimatedata.com/climate/norris/montana/united-states/ usmt0240/2017/5 (accessed on 5 June 2018).

49. Wallace, J.M.; Prather, T.S. Herbicide control strategies for Ventenata dubia in the intermountain pacific northwest. Invasive Plant Sci. Manag. 2016, 9, 128-137. [CrossRef]

50. Whitson, T.D.; Koch, D.W. Control of downy brome (Bromus tectorum) with herbicides and perennial grass competition. Weed Technol. 1998, 12, 391-396. [CrossRef]

51. Rinella, M.J.; Bellows, S.E. Evidence-targeted grazing benefits to invaded rangelands can increase over extended time frames. Rangel. Ecol. Manag. 2016, 69, 169-172. [CrossRef]

52. Rice, P.M.; Toney, J.C.; Bedunah, D.J.; Carlson, C.E. Plant community diversity and growth form responses to herbicide applications for control of centaurea maculosa. J. Appl. Ecol. 1997, 34, 1397-1412. [CrossRef]

53. Sebastian, D.J.; Sebastian, J.R.; Nissen, S.J.; Beck, K.G. A potential new herbicide for invasive annual grass control on rangeland. Rangel. Ecol. Manag. 2016, 69, 195-198. [CrossRef]

(C) 2019 by the authors. Licensee MDPI, Basel, Switzerland. This article is an open access article distributed under the terms and conditions of the Creative Commons Attribution (CC BY) license (http://creativecommons.org/licenses/by/4.0/). 